\title{
The Effect of Working Capital Turnover on Company Liquidity at PT. Gudamg Garam, Tbk (Case study on the Indonesian stock exchange)
} (2007-2011)

\author{
Endang Naryono and Tedi Pitri \\ Info@stiepasim.ac.id
}

\begin{abstract}
This study aims to determine the working capital turnover of PT Gudang Garam, the development of the company's performance at PT Gudang Garam, and to determine the effect of working capital turnover on the company's performance at PT Gudang Garam, Tbk. The research method used is the ex-post facto method. This study uses primary data and secondary data obtained from financial and non-financial reports from PT Gudang Garam. To test the hypothesis, simple regression was used. Based on the results of the analysis, it shows that there is a positive influence between working capital turnover at PT Gudang Garam. The level of closeness of the relationship (correlation) of the two variables is quite strong, namely $r=0.752$ with a correlation coefficient value of $r>0$. The level of influence achieved is $56.55 \%$, and the remaining $43.45 \%$ is influenced by other factors. Meanwhile, by testing the hypothesis by using the $t$-test, the $t$-count value $=5.947$ and the $t$-table value $=0.997$. Based on the t-count value, the T-count value is greater than T-table HO is in the rejection area. The results of simple linear regression analysis that every $1 X$ (times) increase in working capital turnover, the company's performance will increase by $7.462 \%$.
\end{abstract}

Keywords: Capital Turnover, Company Liquidity

\section{A. PENDAHULUAN}

1. Latar Belakang

Efektifitas dari perolehan manajemen penggunaan modal dan manajemen pengelolaan kas. Jenis usaha PT Gudang Garam tersebut menunjukkan pentingnya kemampuan dari PT Gudang Garam dalam efektifitas perputaran modal. Namun apabila suatu perusahaan tidak memiliki modal yang cukup maka perusahaan tersebut akan mengalami penurunan kegiatan operasi. Selain dari itu PT Gudang Garam yang tidak memiliki modal yang cukup juga akan mengalami masalah dalam hal likuiditas. Untuk menguji efisiensi penggunaan modal kerja, penganalisis dapat menggunakan perputaran modal kerja (working capital turnover), yakni rasio antara penjualan dengan modal kerja, Jumingan (2006:132) Menurut Riyanto (2008:25) Likuiditas adalah kemampuan perusahaan dalam melakukan pembayaran kewajiban- kewajiban yang harus segera dipenuhi"." likuiditas terkait dengan masalah kemampuan PT Gudang Garam untuk memenuhi kewajiban finansialnya yang segera harus dipenuhi. Ukuran likuiditas yang menggambarkan tingkat likuiditas PT Gudang Garam ditunjukkan dengan rasio likuiditas. PT Gudang Garam yang memiliki likuiditas sehat paling tidak memiliki current ratio sebesar $100 \%$. Rasio Likuiditas digunakan untuk mengukur kemampuan perusahaan dalam menjamin kewajiban-kewajiban lancarnya. Rasio ini antara lain Cash Ratio, Quick Ratio, Current ratio.

Tingkat likuiditas yang terlalu tinggi maupun terlalu rendah akan sangat mengganggu kegiatan operasional PT Gudang Garam sehingga menghambat tingkat pertumbuhannya. Oleh sebab itu pengelolaan modal secara tepat akan dapat membantu menyeimbangkan rasio 
likuiditas PT Gudang Garam serta mampu memperlancar kegiatan operasional PT Gudang Garam tersebut.Berdasarkan uraian tersebut maka peneliti tertarik untuk melakukan penelitian tentang “ Pengaruh Perputaran Modal Kerja Terhadap Likuiditas Perusahaan (studi survei PT Gudang Garam Tbk. Di Bursa Efek Indonesia).

\section{Rumusan Masalah}

Berdasarkan latarbelakang tersebut diatas, maka penulis mengidentifikasi pokok masalahnya sebagai berikut

1. Bagaimana perputaran modal kerja PT Gudang Garam, Tbk .

2. Bagaimana likuiditas PT Gudang Garam, Tbk .

3. Bagaimana pengaruh modal kerja terhadap likuiditas PT Gudang Garam .

\section{Maksud dan Tujuan}

Maksud dari penelitian ini adalah untuk memenuhi salah satu syarat yang harus dipenuhi dalam menempuh ujian Sarjana Ekonomi Jurusan Akuntansi pada STIE Pasim Sukabumi.

Tujuan dari penelitian ini adalah :

1. Untuk mengetahui perputaran modal kerja PT Gudang Garam .

2. Untuk mengetahui, analisis dan memahami likuiditas PT Gudang Garam.

3. Untuk mengetahui, analisis dan memahami pengaruh perputaran modal kerja terhadap likuiditas PT Gudang Garam

\section{Kerangka Pemikiran}

Menurut Bambang Riyanto (2008;25) pengertian likuiditas dinyatakan sebagai berikut : "Likuiditas adalah berhubungan dengan masalah kemampuan suatu perusahaan untuk memenuhi kewajiban finansialnya yang segera harus dipenuhi". Berdasarkan hal tersebut maka perlu dilakukan analisis yang akurat terhadap modal kerja, agar likuiditas perusahaan dapat dikendalikan, yaitu tetap pada tingkat ideal, oleh sebab itu, penelitian ini berusaha untuk mengunkapkan bagaimana cara perusahaan merumuskan modal kerja dan bagaimana pengaruhnya tehadap likuiditas perusahaan tersebut

Martono, dkk (2002:76) menyatakan terdapat hubungan antara modal kerja dengan kemampuan perusahaan dalam memperoleh laba, dan konsep yang mendasari manajemen modal kerja yang sehat adalah dua keputusan yang menyangkut persoalan dasar perusahaan, yaitu sebagai berikut :

1. Tingkat optimal dari investasi pada aktiva lancar.

2. Perpaduan yang sesuai antara pembiayaan jangka pendek dan jangka panjang yang digunakan untuk mendukung investasi pada aktiva lancar.

Kerangka pemikiran diatas, dapat digambarkan paradigma penelitian sebagai berikut :

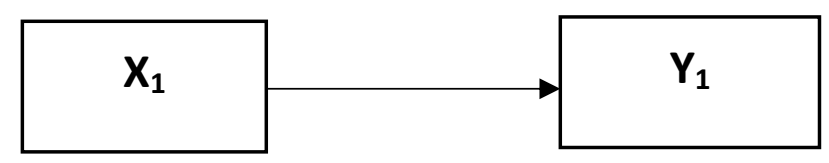

Gambar 1.2 Paradigma Penelitian Keterangan :

$\mathrm{X}$ : Perputaran Modal Kerja

$\mathrm{Y}$ : Likuiditas

\section{B. TINJAUAN TEORI}

\section{Perputaran Modal}

Antara penjualan dengan modal kerja terdapat hubungan yang erat. Apabila volume penjualan naik, investasi dalam persediaan dan piutang juga meningkat, ini berarti juga meningkatkan modal kerja. Modal kerja selalu dalam keadaan operasi atau berputar dalam perusahaan selama perusahaan yang bersangkutan dalam keadaan usaha. Jumingan (2006:132) mengemukakan pendapatnya sebagai berikut:

"Untuk menguji efisiensi penggunaan modal kerja, penganalisis dapat menggunakan perputaran modal kerja (working capital turnover), yakni rasio antara penjualan dengan modal kerja. Perputaran modal kerja ini menunjukkan 
jumlah rupiah penjualan neto yang diperoleh bagi setiap rupiah modal kerja". Sedangkan Ardiyos (2003.:995) mengemukakan pengertian perputaran modal kerja (working capital turnover) sebagai berikut: "Penjualan dibagi dengan rata-rata modal kerja. Perbandingan ini menunjukkan efektivitas badan usaha dalam menggunakan modal kerja untuk memperoleh penerimaan".

Jadi dapat dijelaskan bahwa perputaran modal kerja menunjukkan hubungan antara penjualan dengan modal kerja yang digunakan untuk menilai keefektifan modal kerja suatu perusahaan dalam menghasilkan penerimaan atau penjualan. Dari hubungan antara penjualan dengan modal kerja tersebut dapat diketahui juga apakah perusahaan bekerja dengan modal kerja yang tinggi atau bekerja dengan modal kerja rendah. Perputaran modal kerja yang tinggi diakibatkan rendahnya modal kerja yang ditanam dalam persediaan dan piutang, atau dapat juga menggambarkan tidak tersedianya modal kerja yang cukup dan adanya perputaran persediaan dan perputaran piutang yang tinggi. Jika perputaran persediaan dan perputaran piutang tinggi, berarti perusahaan tidak membutuhkan saldo persediaan dan saldo piutang yang besar, dengan demikian maka jumlah modal kerja pun tidak terlalu besar. Tidak cukupnya modal kerja mungkin disebabkan banyaknya utang jangka pendek yang sudah jatuh tempo sebelum persediaan dan piutang dapat diubah menjadi uang kas. Perputaran modal kerja yang rendah dapat disebabkan karena besarnya modal kerja neto, rendahnya tingkat perputaran persediaan dan piutang atau tingginya saldo kas dan investasi modal kerja dalam bentuk surat-surat berharga.

Masalah yang cukup penting dalam pengelolaan modal kerja adalah menentukan seberapa besar kebutuhan modal kerja suatu perusahaan. Hal ini penting karena bila modal kerja perusahaan terlalu besar berarti ada sebagian dana yang menganggur dan dana ini akan menurunkan tingkat profitabilitas perusahaan. Demikian pula bila modal kerja terlalu kecil akan ada resiko proses produksi perusahaan kemungkinan akan terganggu. Oleh karena itu perlu ditentukan berapa besar kebutuhan modal suatu perusahaan.

\section{Likuiditas Perusahaan}

Munawir (2002;31) mengemukakan definisi likuiditas sebagai berikut:

"Likuiditas adalah menunjukkan kemampuan suatu perusahaan untuk memenuhi kewajiban keuangannya yang hams segera dipenuhi, atau kemampuan perusahaan untuk memenuhi kewajiban keuangan pada saat ditagih". Sedangkan menurut Syamsuddin $(2002 ; 41)$, dalam bukunya berpendapat bahwa:

"Likuiditas merupakan suatu indikator mengenai kemampuan perusahaan untuk membayar semua kewajiban finansial jangka pendek pada saat jatuh tempo dengan menggunakan aktiva lancar yang tersedia". Sementara menurut Riyanto (2001;25), mengemukakan bahwa:

"Masalah likuiditas adalah berhubungan dengan masalah kemampuan suatu perusahaan untuk memenuhi kewajiban finansialnya yang segera hams dipenuhi". Berdasarkan beberapa pendapat di atas dapat dikatakan bahwa pengertian likuiditas adalah kemampuan suatu perusahaan untuk memenuhi atau membayar kewajiban keuangan jangka pendek yang hams segera dipenuhi.

Faktor-faktor yang Menentukan Likuiditas

Faktor-faktor yang perlu diperhatikan dalam menentukan likuiditas dapat dibagi dalam tiga bagian sebagai berikut:

a. Besarnya investasi pada harta tetap dibandingkan dengan seluruh data jangka panjang

Pemakaian dana untuk pembelian harta tetap adalah salah satu sebab utama dari 
keadaan tidak likuid. Jikalau makin banyak dana perusahaan yang dipergunakan untuk harta tetap, maka sifatnya untuk membiayai kebutuhan jangka pendek tinggal sedikit. Oleh sebab itu rasio likuiditas menurun. Kemerosotan tersebut hanya dapat dicegah dengan menambah dana jangka panjang untuk menutup kebutuhan harta tetap yang meningkat.

b. Volume kegiatan perusahaan,

Peningkatan volume kegiatan perusahaan akan menambah kebutuhan dana untuk membiayai harta lancar. Sebagian dari kebutuhan tersebut dipenuhi dengan meningkatkan hutang-hutang, tetapi jika hal-hal lain tetap, investasi dana jangka panjang untuk membiayai tambahan kebutuhan modal kerja sangat diperlukan agar rasio dapat dipertahankan.

c. Pengendalian harta lancar.

Apabila pengendalian yang kurang baik terhadap besarnya investasi dalam persediaan dan piutang menyebabkan adanya investasi yang melebihi daripada yang seharusnya, maka sekali lagi rasio akan turun dengan tajam, kecuali apabila disediakan lebih banyak dana jangka panjang. Kesimpulannya ialah bahwa perbaikan dalam pengendalian investasi semacam itu akan dapat memperbaiki rasio likuiditas

\section{Pengaruh Perputaran Modal Terhdap Likuiditas Perusahaan}

Terdapat pengaruh antara modal kerja terhadap likuiditas, hal ini didukung dengan teori dibawah ini.Adanya keterkaitan antara modal kerja dengan likuiditas dijelaskan oleh Kasmir (2010:215) bahwa "dalam salah satu tujuam modal kerja adalah untuk digunakan memenuhi kebutuhan likuiditas, artinya likuiditas sangat tergantung kepada modal kerja". Mengingat laporan sumber dan penggunaan modal kerja memuat elemen- elemen dari rekening lancar, maka analisis yang tajam dan akurat terhadap laporan sumber dan penggunaan modal kerja dapat dijadikan alat untuk alat untuk pengendalian perubahan likuiditas perusahaan. Selanjutnya perusahaan memenuhi seluruh kewajiban keuangannya tepat pada waktunya maka perusahaan itu disebut "likuid", tapi jika perusahaan tersebut tidak dapat memenuhi kewajiban keuanganya tidak tepat pada waktunya maka perusahaan itu disebut "Likuiditas".

\section{METODE PENELITIAN}

\section{Unit Analisis}

Unit analisis adalah unit yang akan digunakan untuk menjelaskan atau menggambarkan karakteristik dari kumpulan objek yang lebih besar lagi (Bambang S.Soedibjo, 2005:38). Sedangkan menurut Suharsimi (2006:143) Unit Analisis adalah satuan tertentu yang diperhitungkan sebagai subjek penelitian. Unit analisis dapat berupa individu, kelompok, organisasi atau artefak. Dalam penelitian ini yang menjadi unit analisis adalah data yang berasal dari laporan keuangan perusahaan, yaitu neraca, laporan laba rugi, dan laporan arus kas. Jenis data yang dipergunakan dalam penelitian ini ialah :

1. Data Kualitatif

Data kualitatif ialah data yang berbentuk kata, kalimat, skema, dan gambar. Jenis data kualitatif ini ialah data sekunder yaitu data yang telah mengalami proses pengolahan oleh sumbernya.

2. Data Kuantitatif

Data kuantitatif adalah data yang disajikan dalam bentuk angka. Data ini menunjukan nilai terhadap besaran atau variabel yang diwakilinya. Sifat data ini ialah data rentet waktu yaitu data yang merupakan hasil pengamatan dalam suatu periode tertentu. Objek penelitian yang akan digunakan ialah 
Laporan Keuangan dari PT Gudang Garam. Data penelitian ini merupakan gabungan antara deret waktu (time series) dan satu waktu untuk suatu fenomena (cross section) selama kurun waktu 5 tahun, yakni mulai dari tahun 2007 sampai dengan tahun 2011.

\section{Populasi dan Sample}

Metode sampel yang digunakan adalah metode pemilihan sampel bertujuan (purposive sampling), yaitu merupakan metode pemilihan sampel secara tidak acak (non-probabilitas) dari populasi yang datanya mudah diperoleh peneliti.

Penulis memilih sampel dari suatu populasi laporan keuangan (neraca dan laporan laba-rugi), yang diterbitkan oleh PT Gudang Garam.. Populasi tersebut adalah populasi tidak terbatas karena diasumsikan laporan-laporan akan terus terjadi dan diterbitkan oleh PT Gudang Garamdimasa yang akan datang. Selanjutnya penulis menetapkan jumlah sampel yang akan digunakan dalam penelitian ini adalah laporan keuangan periode tahun 2007-2011, yang dibagi kedalam 3 bagian, sehingga diperoleh $\mathrm{n}$ $=3$.

\section{Defisnisi Operasional Variable}

Sesuai dengan judul skripsi yang dipilih yaitu pengaruh perputaran modal kerja terhadap kinerja perusahaan, maka terdapat dua variabel penelitian yaitu:

1. Variabel Independen (X)

Adalah suatu variabel bebas yang keberadaannya tidak dipengaruhi oleh variabel lain, bahkan merupakan faktor penyebab yang akan mempengaruhi variabel-variabel lain.

Variabel X : Perputaran Modal Kerja

Keefektifan penggunaan modal kerja dari suatu perusahaan ditunjukkan oleh perputaran modal kerjanya. Dalam penelitian ini penulis menggunakan rasio perputaran modal kerja bersih (net working capital), dengan rumus :

\section{Pendapatan}

Modal Kerja Neto

2. Variabel dependen

Variabel dependen atau variabel tergantung, yaitu variabel yang dipengaruhi oleh variabel lainnya, maka yang menjadi variabel dependen adalah tingkat likuiditas perusahaan

\section{Analisis Regresi Linier Sederhana}

Kegunaan analisis regresi linier sederhana menurut Sarwono(2005:95) adalah sebagai berikut : "Untuk mengukur besarnya pengaruh variabel bebas terhadap variabel tergantung dan memprediksi variabel tergantung dengan menggunakan variabel bebas". Menurut Sugiyono (2009:261) menyatakan bahwa: "Regresi linier sederhana didasarkan pada hubungan fungsional ataupun kausal satu variabel independen dengan satu variabel dependen". Analisis regresi digunakan untuk mempelajari hubungan yang ada diantara variabel bebas (X) dengan variabel terikat (Y). pola hubungan berbentuk garis lurus (linear), dinyatakan dalam bentuk persamaan: $\quad \mathrm{Y}=\mathrm{a}+\mathrm{bx}$

Dimana:

Y : Subjek dalam variabel dependen yang diprediksi ( kinerja perusahaan)

a : Harga $\mathrm{Y}$ bila $\mathrm{x}=0$ ( kinerja perusahaan jika perusahaan tidak menggunakan perputaran modal kerja)

b : Angka arah yang menunjukkan angka peningkatan ataupun penurunan variabel

dependen yang didasarkan pada variabel independent (kecenderungan perubahan kinerja perusahaan sebagai akibat perubahan perputaran modal kerja)

$X$ : Subjek variabel independent (perputaran modal kerja)

\section{Analisis Korelasi}

Rumus koefisien korelasi Rho Spearman (Bambang S. Soedibjo, 2005:150):

$$
r s=1-\frac{6 . \sum d^{2}}{N\left(N^{2}-1\right)}
$$




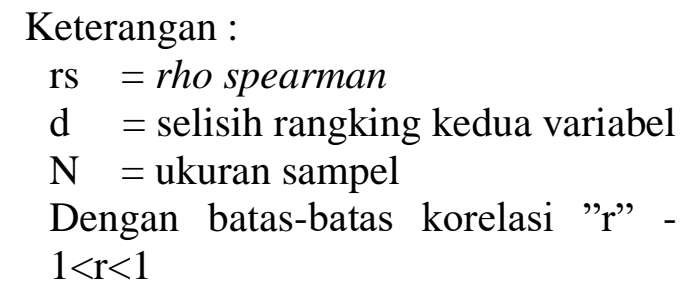

1. Jika $\mathrm{r}$ bernilai positif, maka terdapat hubungan yang searah diantara variabel bebas dan variabel tidak bebas akan bertambah besar, jadi bersifat sama.

2. Jika $\mathrm{r}$ bernilai 0 (nol), maka tidak ada hubungan antara variabel bebas dan variabel tidak bebas .

3. Jika $r$ bernilai negatif, maka terdapat hubngan yang berlawanan arah antara variabel bebas dan variabel tidak bebas (jika variabel bebas bertambah besar maka variabel tidak bebas bertambah kecil). Jika nilai korelasi (r) bertambah besar, maka hal ini menunjukan hubungan antara variabel bebas dan variabel tidak bebas semakin kuat, demikian pula sebaiknya.

\section{Koefisien Determinasi}

Untuk mengetahui berapa besar kontribusi atau sumbangan variabel $\mathrm{X}$ terhadap variabel $\mathrm{Y}$ maka digunakan rumus koefisien determinan, dengan rumus sebagai berikut:

$$
\mathrm{Kd}=\mathrm{r}^{2} \times 100 \%
$$

Keterangan :

$\mathrm{Kd}:$ Koefisien determinasi

$\mathrm{r} \quad$ : Koefisien korelasi

\section{PEMBAHASAN}

Persamaan regresi yang digunakan adalah persamaan regresi linier, yaitu $\mathrm{Y}=\mathrm{a}+\mathrm{bx}$. merupakan Likuiditas Perusahaanyaitu fungsi dari perputaran modal kerja atau x. konstanta a adalah tingkat Likuiditas Perusahaanjika perusahaan tidak menggunakan perputaran modal kerja. Konstanta $b$ adalah kecenderungan perubahan Likuiditas Perusahaanakibat perubahan perputaran modal kerja.
Tabel 1.

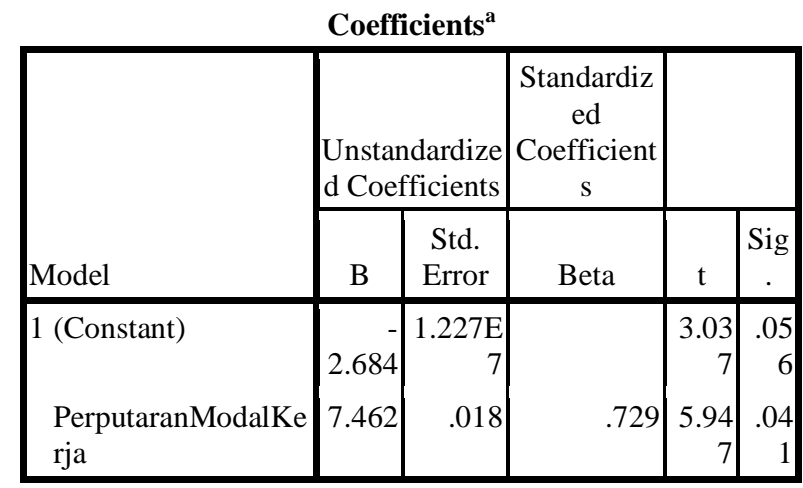

a. Dependent Variable: Likuiditas Perusahaan

Berdasarkan perhitungan diatas maka didapat persamaan regresi untuk perputaran modal kerja terhadap Likuiditas Perusahaan adalah:

$$
=-2.684+7.462
$$

Dari persamaan regresi tersebut menunjukkan bahwa hubungan antara perputaran modal kerja dengan Likuiditas Perusahaan adalah positif, sehingga bila perputaran modal kerja meningkat maka Likuiditas Perusahaa nmeningkat. Hal tersebut dilihat dari nilai konstanta $\mathrm{b}$ yang positif, yang menunjukkan bahwa apabila perputaran modal kerja $0 \mathrm{X}$ (kali),- maka besanya Likuiditas Perusahaan. $2.684 \%$, yang artinya apabila perputaran modal kerjanya $0 \quad \mathrm{X}$ (kali/tidak ada perputaran),- maka perusahaan akan mengalami kerugian sebesar $2.684 \%$. dan koefisien regresi $\mathrm{x}$ sebesar 7.462 menunjukkan bahwa setiap peningkatan perputaran modal kerja 1X (kali), maka akan meningkatkan Likuiditas Perusahaansebesar $7.462 \%,-$ (karena tanda positif).

\section{Analisis Korelasi}

Untuk melihat derajat keeratan antara variabel independen dan variabel dependen digunakan kriteria Champion (Bambang S.Soedibjo, 2005:126) 
Tabel 2.

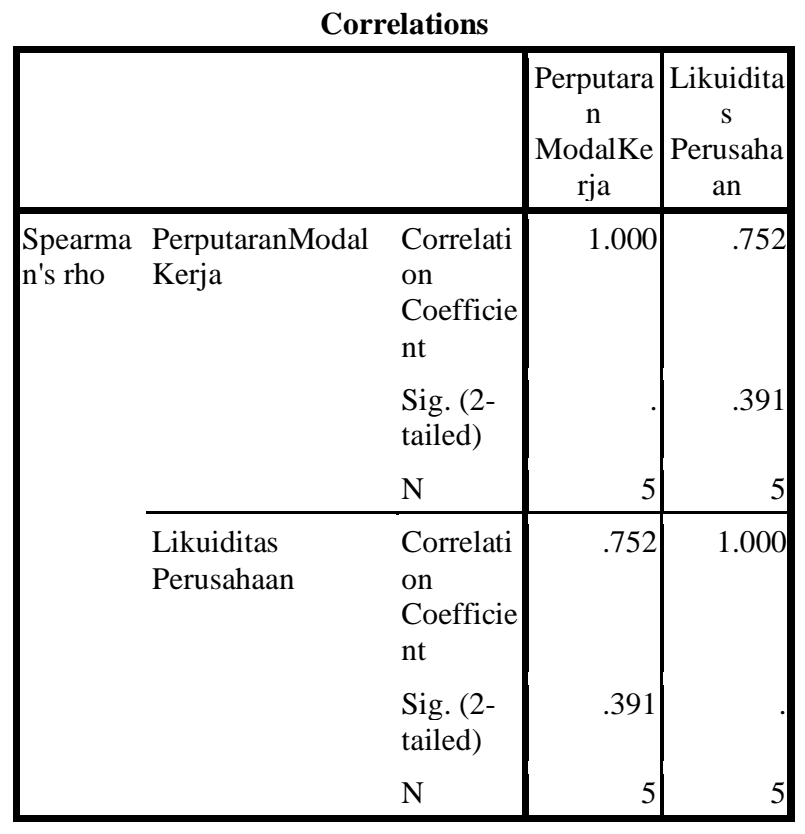

Berdasarkan perhitungan diatas dapat diperoleh koefisien korelasi sebesar 0,752 dengan jumlah sampel 5 . Hal ini menunjukan besanya perputaran modal kerja terhadap Likuiditas Perusahaan memiliki korelasi yang cukup kuat. Artinya, setiap kenaikan jumlah modal kerja akan diikuti dengan kenaikan Likuiditas perusahaan. Demikian juga adanya penurunan jumlah modal kerja akan diikuti dengan penurunan Likuiditas perusahaan.

\section{Analisis Determinasi}

Koefisien determinasi digunakan untuk menentukan besanya pengaruh variabel $X$ (Independent variable) terhadap variable Y (Dependent variable), sedangkan koefisien non determinasi untuk menentukan besanya pengaruh faktor- faktor lain terhadap Y. Hasil koefisien dinyatakan dalam persen koefisien determinasi. Dari hasil perhitungan koefisien korelasi Rho Spearman, maka dapat ditentukan bahwa koefisien determinasi perputaran modal kerja terhadap Likuiditas Perusahaanadalah:

$$
\begin{aligned}
& \mathrm{kd}=\mathrm{r} 2 \times 100 \% \\
& \mathrm{kd}=0,7522 \times 100 \% \mathrm{kd}=56,55 \%
\end{aligned}
$$

dari nilai $\mathrm{kd}$, diperoleh nilai $\mathrm{R}$ sebesar 0,752 . Maka dapat disimpulkan bahwa besarnya pengaruh positif perputaran modal kerja terhadap Likuiditas Perusahaan yang terjadi dalam perusahaan adalah sebesar $\quad 56,55 \%$ dan sisanya sebesar $43,45 \%$ dipengaruhi oleh variabel lain terhadap Likuiditas Perusahaan yang terjadi di dalam perusahaan. Dari hasil perhitungan dengan menggunakan koefisien regresi dan koefisien korelasi pada bagian diatas menyatakan bahwa Ho ditolak, hal ini berarti bahwa perputaran modal kerja memiliki pengaruh yang signifikan terhadap Likuiditasperusahaan.

\section{E. KESIMPULAN DAN SARAN Kesimpulan}

Berdasarkan hasil penelitian dan pembahasan dalam bab IV maka penulis dapat menarik kesimpulan sebagai berikut :

1. Perputaran modal kerja pada perusahaan yang berlangsung selama tahun 2002 sampai dengan 2004 dapat dilihat dari perhitungan perputaran modal kerja dari tiap perusahaan pada tabel 4.2. Dari tabel tersebut dapat disimpulkan bahwa dalam menjalankan usahanya perusahaan menggunakan modal kerja yang berbeda dari tiap tahun dalam menghasilkan penjualan sehingga tingkat perputaran modal kerja pada perusahaan selalu mengalami kenaikan dan penurunan dengan rata-rata 5,16 kali atau $516 \%$. Tingkat perputaran modal kerja yang rendah menunjukkan adanya modal kerja yang tidak produktif pada perusahaan.

2. Berdasarkan perhitungan dengan menggunakan rasio likuditas yang terdiri dari rasio lancar, rasio cepat, rasio kas dapat disimpulkan bahwa tingkat likuiditas perusahaan mengalami perubahan dari tahun ke tahun tetapi perusahaan tetap dapat memenuhi kewajiban jangka pendeknya dengan nilai 
aktiva lancar perusahaan lebih besar daripada hutang lancar sebesar $100 \%$.

3. Dari analisis yang telah dilakukan penulis, maka hasil yang diperoleh menunjukkan bahwa:

- Nilai Korelasi $\mathrm{r}=0,752$, artinya terdapat hubungan yang cukup kuat antara perputaran modal kerja dengan Likuiditas perusahaan.

- Nilai Koefisien Determinasi (KD) sebesar 0,5655 atau 56,55\%, artinya besarnya pengaruh antara perputaran modal kerja terhadap Likuiditas perusahaan 56,55\%. Dan dipengaruhi oleh variabel lainnya sebesar $43,45 \%$.

- Nilai analisis regresi linier sederhana bahwa Setiap peningkatan 1X (kali) perputaran modal kerja maka Likuiditasperusahaan akan naik sebesar $7.462 \%$.

- $\quad$ Thitung $>$ Ttabel yaitu 5,947 >0,997 yang berarti bahwa perputran modal kerja berpengaruh positif terhadap

\section{Saran}

Likuiditas perusahaan

Pada kesempatan ini penulis juga ingin menyampaikan beberapa saran, yang mudahmudahan dapat dijadikan masukan bagi perusahaan untuk langkah perbaikan selanjutnya. Adapun saran-saran yang dimaksudkan adalah sebagai berikut :

1. Agar pengelolaan modal kerja sesuai dengan kebutuhan perusahaan, sehingga perputaran modal kerja bisa semakin meningkat.

2. Perusahaan harus dapat mengelola aktiva terutama pada investasi aktiva tetap, sehingga peningkatan pendapatan dapat meningkatkan Likuiditas perusahaan.

3. Dengan adanya pengaruh perputaran modal kerja yang cukup kuat terhadap Likuiditasperusahaan pada PT Gudang Garam, maka diharapkan agar perusahaan dapat mempertahankannya dengan lebih memfokuskan pada perputaran modal kerja dengan begitu Likuiditas PT Gudang Garam dapat lebih baik.
Amin Widjaja Tunggal,1995, "Dasar-dasar Analisis Laporan Keuangan",Cetakan pertama, Jakarta, PT Rineka Cipta

Agnes Sawir,2003, "Anaisis Kinerja Keuangan dan Perencanaan Keuangan Perusahaan", Cetakan kedua, Jakarta, PT Gramedia Pustaka Utama

Anto Dajan, 1996, Pengantar Metode Statistik jiid II, Cetakan kedelapan belas, Jakarta : Penerbit PT. Pustaka LP3ES

Bambang Riyanto, 2001, "Dasar-dasar Pembelanjaan Perusahaan", Edisi keempat, Cetakan ketujuh, Yogyakarta: BPFE

Dwi Prastowo dan Rifka Juliaty,2002, "Anaisa Laporan Keuangan", Edisi kedua, Yogyakarta, YPKN

M. Nazir, Juli 1999, "Metode Peneitian", Cetakan keempat, Jakarta : :Ghalia Indonesia

S. Munawir,2002, "Anaisa Laporan Keuangan", Edisi keempat, Cetakan ketiga belas, Yogyakarta, Liberty

Sofyan Safri Harahap,2001, "Anaisa Kritis Atas Laporan Keuangan", Cetakan ketiga, Jakarta, PT Raja Grafindo Persada

Sugiyono,2004,MetodePenelitianBisnis,Cetak ankeenam, Bandung,Penerbit CV Alvabeta

Sugiyono, 2005, Statistika Untuk Peneitian, Cetakan ketujuh, Bandung,Penerbit CV Alvabeta

Sutrisno, 2001, Manajemen Keuangan Teori, Konsep dan Aplikasi, Edisi pertama, Cetakan kedua, Yogyakarta, Ekonisia

\section{PUSTAKA}

